\title{
THE EFFECT OF TEACHER PROFESSIONAL COMPETENCE AND LEARNING FACILITY ON STUDENTS' LEARNING MOTIVATION
}

\author{
Iin Sunarti \\ Department of Economy Education, Faculty of Teacher Training and Education, University of \\ Kuningan, Indonesia \\ E-mail: iinsunarti56@gmail.com \\ Teni Rumyani \\ Department of Economy Education, Faculty of Teacher Training and Education, University of \\ Kuningan, Indonesia
}

\begin{abstract}
APA Citation: Sunarti, I., \& Rumyani, T. (2018). The effect of teacher professional competence and learning facility on students' learning motivation. Indonesian Journal of Learning and Instruction, 1(2), 45-54.
\end{abstract}

\begin{abstract}
This research aims to find out the effect of teacher professional competence and learning facility on students learning motivation. The research method used by the researcher is the survey method. For the measurement uses Likert scale 5 options spreaded to 174 respondents. From the result of validity test, the variable X1 had 18 valid items, the variable X2 had 20 valid items, and variable $\mathrm{Y}$ had 18 valid items. The instrument reliability for the three variables are reliable. The data analysis uses double regression. Based on the result of the research, the questionnaire score gained for variable $\mathrm{X} 1$, variable $\mathrm{X} 2$ and variable $\mathrm{Y}$ was categorized high criterion. Based on the result of calculation of double regression analysis, it shows that teacher professional competence and learning facility had positive and significant effect on students learning motivation both partially and simultaneously. Therefore, to increase the students learning motivation, the teacher professional competence and learning facility should be increased, those are: 1) Teacher should master the learning material and improve the attractive learning method or media to increase students learning motivation; 2) The teacher should create pleasant learning atmosphere so the learning process can run effectively; 3) The students are expected to increase their reading so they can utilize their own ability and not depend on other's opinion.

Keywords: teacher competence; learning facility; learning motivation.
\end{abstract}

\section{INTRODUCTION}

Motivation is an effort realized to propel, direct and keep one's behavior so he is encouraged to act or do something to reach certain purpose. So, motivation can be made learning strengthener, to clarify learning objectives that will be reached, and to determine learning diligence.

In fact, students learning motivation are various. There is high motivation, moderate motivation, and even low motivation, as on the students of Class VIII National Junior High School 3 Kuningan. There are still students who are less serious in the learning: they pay less attention to the teacher while in the teaching and learning activity, they do not have enthusiasm to come after the lesson, and they are absent-minded in doing task given by the teacher. There are many factors that can affect students learning motivation, such as teacher professional competence and learning facility.

Teacher professional competence is a competence or ability related to the teaching tasks completion. Professional Competence is expected to be fulfilled that teacher should master the effective learning method, can manage learning so that students will not get bored because teacher can manage the learning activity become pleasant learning 
activity that motivates students to learn and perform well.

Besides the teacher professional competence, students learning facility also has important role in their learning process because learning facility is everything that can facilitate and smooth the teaching and learning process at school, such as the availability of learning place (class room), teaching visual aids, textbook, library, laboratory and any learning supporting facility. Therefore, professional competence and supporting learning facility can increase students learning motivation.

Based on the explanation above, the researcher conducted the research entitled The Effect of Teacher Professional Competence and Learning Facility on Students Learning Motivation of Class VIII National Junior High School 3 Kuningan.

Based on the background explained above, the researcher formulated research problems as follows: 1) How are the description of teacher professional competence, learning facility and students learning motivation of Class VIII at National Junior High School 3 Kuningan? 2) How is the effect of teacher professional competence and learning facility on students learning motivation of Class VIII at National Junior High School 3 Kuningan? 3) How is the effect of teacher professional competence on students learning motivation of Class VIII at National Junior High School 3 Kuningan? 4) How is the effect of learning facility on students learning motivation of Class VIII at National Junior High School 3 Kuningan?

Motivation comes from the word 'motive' that can be defined as driving force existing in one's self to do certain activity for the goal achievement. According to Purwanto (2010: 61), motivation is a complex statement in an organism that directs behavior to a goal or incentive. Motivation is viewed as mental propulsion that propels and directs human behavior, including learning behavior.

In running his role and function, a teacher should be supported by various competencies so that he maximizes his performance. According to Sudrajat (2011, p. 116), he explains that:

Basically, competence is the description about what should be able to do by someone in a task, such as activity, behavior and result that should be presented or shown. To be able to do something in his job, someone surely needs to have ability in form of knowledge, attitude, and skill in accordance with his job field."

Suyanto and Hisyam as cited in Sudrajat (2011: 116), state that teacher professional competence is a teacher that has wide knowledge from the subject matter he teaches, chooses and uses various teaching method in the teaching and learning method he organizes.

Beside that, learning facility is extremely important in teaching and learning activity, since with adequate learning facility then learning purpose that has been established will be achieved. Djamarah (2006: 46) says that facility is everything that facilitates students. While, Sopiatin (2010: 73) argues that learning facility is medium and infrastructure that have to be available to smooth the educational activity at school. It can be concluded that learning facility is medium and infrastructure that can smooth the students teaching and learning process in order to make the purpose of education itself can run smoothly, regularly, effectively, and efficiently.

\section{METHOD}

To conduct a research needed appropriate research method to get the conclusion. The use of research method was accustomed with the research objectives and situation so the instrument or technique that would be used can be established.

The method used in this research was survey method. Sugiyono (2015: 12) stated that survey method was used to obtained data from certain place that was natural (not artificial), but the research did some treatments in data collection, such as 
Indonesian Journal of Learning and Instruction Volume 1, Issue 2, October 2018

spreading questionnaire, test, structured interview, and so on.

Variable was something that was valuated. It was in accordance with Sugiyono's (2015:60) opinion who proposed that variable was everything in any form that is determined by the researcher to be studied until the information about the variable was obtained, then it drew the conclusion.

Variable in this research consisted of two unbound variables that were teacher professional competence (X1) and Learning Facility (X2), and students learning motivation (Y) as the affected variable.
p-ISSN 2614-8250, e-ISSN 2614-5677

https://journal.uniku.ac.id/index.php/IJLI

This measurement was a complex problem because it was related to the problem of variable function to describe the construct abstraction it represented. The measurement used in this research is Likert scale.

Sugiyono (2015: 134) proposes that Likert scale was used to measure someone's or group's attitude, opinion, and perception about social phenomenon.

The measuring instrument used was questionnaire with five alternative answers as shown in Table 1. On the other hand, the researcher established indicators from each variable as presented in Table 2.

Table 1. Likert scale

\begin{tabular}{llcc}
\hline No & \multicolumn{1}{c}{ Alternative Answer } & \multicolumn{2}{c}{ Measurement } \\
\cline { 3 - 4 } & & Positive & Negative \\
\hline 1 & Always/Very Agree & 5 & 1 \\
2 & Often/Agree & 4 & 2 \\
3 & Sometimes/Doubtful & 3 & 3 \\
4 & Rarely/Less Agree & 2 & 4 \\
5 & Never/Very Disagree & 1 & 5 \\
\hline
\end{tabular}

Table 2. Variable and Measurement

\begin{tabular}{|c|c|c|c|}
\hline Variable & Dimension & Indicator & Measurement \\
\hline $\begin{array}{l}\text { Variable (X1) } \\
\text { (Teacher } \\
\text { Professional } \\
\text { Competence) }\end{array}$ & $\begin{array}{l}\text { 4. Assessing the result and } \\
\text { teaching and learning } \\
\text { process that has been } \\
\text { conducted }\end{array}$ & $\begin{array}{l}\text { a. Mastering teaching } \\
\text { material in curriculum } \\
\text { of primary and } \\
\text { intermediate education } \\
\text { b. Mastering enrichment } \\
\text { material } \\
\text { a. Establishing learning } \\
\text { purpose } \\
\text { b. Selecting and } \\
\text { developing learning } \\
\text { material } \\
\text { c. Selecting and } \\
\text { developing teaching } \\
\text { and learning strategy } \\
\text { d. Selecting and } \\
\text { developing appropriate } \\
\text { learning media } \\
\text { a. Creating proper } \\
\text { teaching and learning } \\
\text { climate } \\
\text { b. Arranging classroom } \\
\text { c. Managing teaching } \\
\text { and learning } \\
\text { interaction } \\
\text { a. Assessing students' } \\
\text { achievement for } \\
\text { teaching importance } \\
\text { b. Assessing teaching and }\end{array}$ & $\begin{array}{l}\text { Positive } \\
\text { Statement } \\
\text { AL/VA = 5 } \\
\text { OF/A = 4 } \\
\text { SO/D = } 3 \\
\text { RA/LA = 2 } \\
\text { N/VD = 1 } \\
\text { Negative } \\
\text { Statement } \\
\text { AL/VA = 1 } \\
\text { OF/A = } 2 \\
\text { SO/D = } 3 \\
\text { RA/LA = 4 } \\
\text { N/VD = 5 }\end{array}$ \\
\hline
\end{tabular}


Iin Sunarti \& Teni Rumyani

The effect of teacher professional competence and learning facility on students' learning motivation

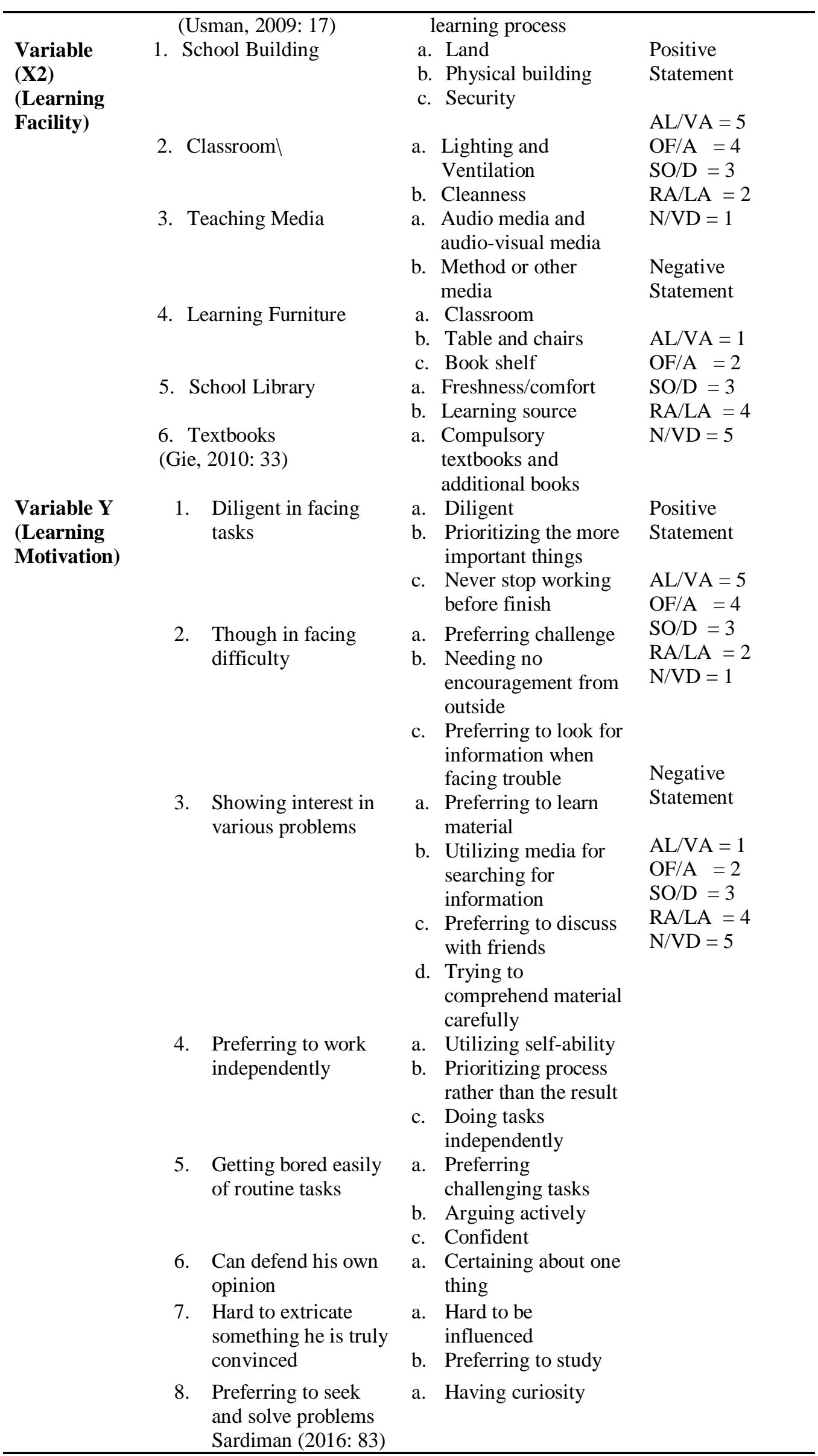


In conducted research activity, data collection was an important step to find out the characteristic of the population that becomes the elements of the research object, and the data was used for the hypothesis testing.

Sugiyono (2015: 117) proposes that population was the generalization region which consists of object/subject that has quality and certain characteristic established by the researcher to be studied and then drawn the conclusion.

Population in this research was 308 people from ten class of VIII National Junior High School 3 Kuningan.

To obtain the sample that became the respondent, the research used Slovin formula (Suharsaputra, 2012: 119) in Quantitative, Qualitative, and Action Research Methods as followed:

$$
\begin{aligned}
& n=\frac{N}{1+N e^{2}} \\
& \text { Explanation: } \\
& n \quad=\text { Sample number } \\
& \mathrm{N}=\text { Population } \\
& e^{2}=\text { Error tolerance that would be } \\
& \text { taken by the researcher }
\end{aligned}
$$

Based on Slovin formula above, the researcher took sample as follows:

$$
\begin{aligned}
& n=\frac{308}{1+308(5 \%)^{2}} \\
& n=174.01 \cdot n=174 \text { (rounded) }
\end{aligned}
$$

Thus, the researcher determined research samples of 174 people.

Sampling technique used in this research was probability sampling technique that was sampling technique to give equal opportunity to each population member to be chosen as sample member. Based on the application, this probability sampling technique was done using proportional random sampling, that was the sampling and allocation that was proportionally based on the total of sampling unit in the strata.

The technique used in this data collection was Questionnaire Distribution that was data collection technique using series of written statements given to the respondents who became research sample members, and this had affect on the indicators on each variable. Questionnaire that was spreaded was closed questionnaire form with Likert scale five categories to measure variable of Teacher Professional Competence $\left(\mathrm{X}_{1}\right)$, Students Learning Facility $\left(\mathrm{X}_{2}\right)$, and Learning Motivation $(\mathrm{Y})$.

In the instrument testing in qustionnaire form, it needed to conduct validity test and realibility test first. In the operational step, validity test and reliability test were supported by using SPSS (Statistical Package for Social Science) 20 program software.

To describe the Teacher Professional Competence (Variable X1), Learning Facility (Variable X2) and Learning Motivation (Variable Y), the researcher used percentage technique. Next, for the hypothesis testing, the researcher did some steps.

There was Statistical Prerequisites Test which contained some tests, namely data conversion, normality test, auto-corrrelation, multicollinearity, and double regression.

Data conversion was done as the rule to use parametric statistic. Since the kind of data collected by the researcher was the ordinal data (rank) so it needed to be converted to interval data (gap inter-data had same weight).

Normality test was done as the rule test of analysis if would be used in Parametric statistic. Besides, to find out whether the sample was distributed normal or not, sample normality test was done using Kolmogorov - Smirnov. Meanwhile, if one of the variable data was not distributed normal, the analysis data would use non-parametric statistic with Rank Spearman Correlation formula.

Auto-correlation was meant to find out whether or not there was correlation between residual in one observation with other observation. For the calculation, the researcher used SPSS for Windows 20 program. While to find out whether or not there was auto-correlation used Durbin Watson (DW) test (Santoso, 2000: 47) in Hanggara (2012: 7). 


\section{Iin Sunarti \& Teni Rumyani}

The effect of teacher professional competence and learning facility on students' learning motivation

Multicollinearity test was to find out whether or not there was high correlation among the unbound variables in a model of doubled linear regression. To find whether or not there was multicollinearity could be seen by comparing VIF (Variance Inflation Factor) value. If the value of VIF calculation result was higher than $10(>10)$ then the variable had multicollinearity with other unbound variables. Conversely, if the value of VIF $<10$ then it could be said that there was no multicollinearity (Santoso, 2000: 39) in Hanggara (2012: 6). For the calculation, the researcher used SPSS for Windows 20 program.

Double regression analysis was the improvement of simple regression analysis. The function was to predict the value of related variable (y) if the unbound variables were two or more.
According to Somantri (2011: 250), double regression analysis was the tool to predict the influence value of two or more unbound variables on one dependent variable (to prove whether or not there was functional relationship or causal relationship between two or more unbound variables $x_{1}, x_{2}, \ldots, x_{i}$ on a dependent variable $\mathrm{Y}$.

For the calculation of double regression, the researcher used SPSS 20 (Statistical Package for Social Science) 20 program.

\section{RESULTS AND DISCUSSION}

In the validity test was used to find out whether an instrument was valid or not when used in the data collection. The calculation result of instrument validity item on each variable was as followed.

Table 3. Calculation result of item analysis on instrument validity test

\begin{tabular}{ccc}
\hline Variable & $\begin{array}{c}\text { Number of } \\
\text { Valid Items }\end{array}$ & $\begin{array}{c}\text { Number of } \\
\text { Invalid Items }\end{array}$ \\
\hline $\mathbf{X}_{\mathbf{1}}$ & 18 Items & 2 Items \\
$\mathbf{X}_{\mathbf{2}}$ & 20 Items & - \\
$\mathbf{Y}$ & 18 Items & 2 Items \\
Total & 56 Items & 4 Items \\
\hline
\end{tabular}

In the reliability testing, the research used Cronbach's Alpha formula supported with SPSS for windows V.17 program. The calculation result of reliability test was as follow:

Table 4. Calculation result of instrument reliability

\begin{tabular}{ccc}
\hline VARIABLE & RELIABLE & CATEGORY \\
\hline $\mathbf{X}_{\mathbf{1}}$ & 0.990 & Very High \\
$\mathbf{X}_{\mathbf{2}}$ & 0.733 & High \\
$\mathbf{Y}$ & 0.965 & Very High \\
\hline
\end{tabular}

Descriptive Analysis

a. Teacher Professional Competence

The value of variable $\mathrm{X} 1$ as $70.22 \%$ was on the high criterion zone that was on the interval $61 \%-80 \%$.

b. Learning Facility

The value of variable $\mathrm{X} 2$ as $69.55 \%$ was on the high criterion zone that was on the interval $61 \%-80 \%$. c. Learning Motivation

The value of variable $\mathrm{Y}$ as $70.94 \%$ was on the high criterion zone that was on the interval $61 \%-80 \%$.

On the other hand, based on the Statistical Prerequisites Test, the result of the research in data normality test could be showed on the table below. 
Table 5. Data normality test

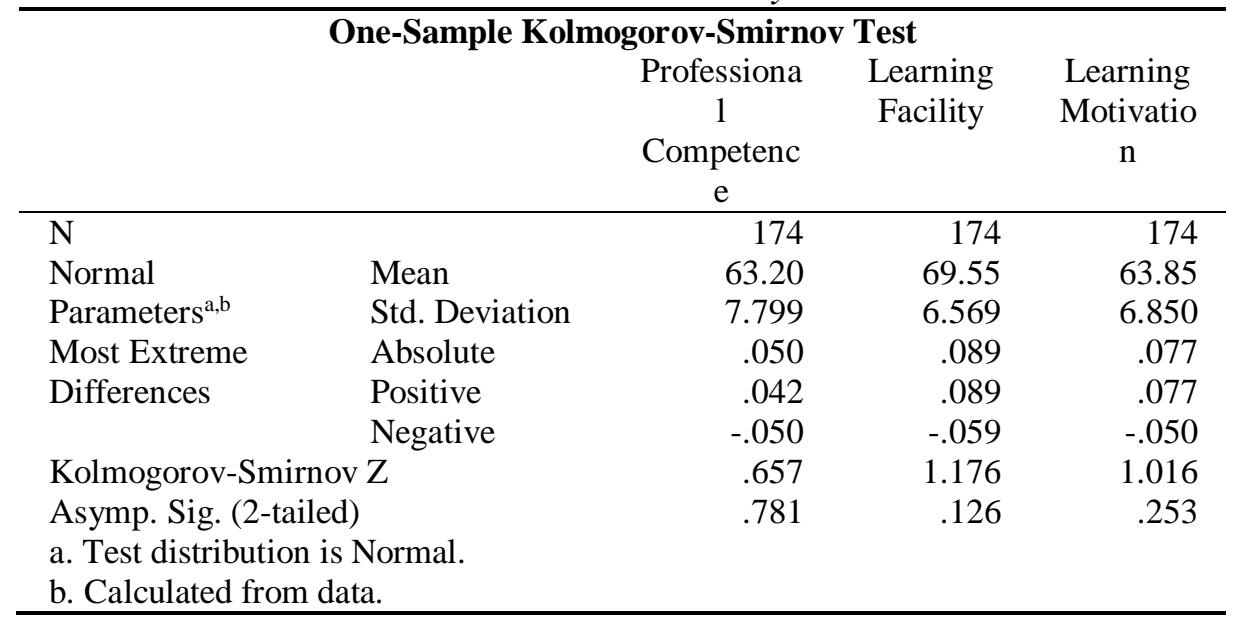

It was seen from the calculation result used SPSS (Statistical Package for Social Science) 20 obtained Kolmogorov Smirnov $\mathrm{X} 1$ as 657 with significance of variable $\mathrm{X} 1$ (Professional Competence) was 0.781, the value of Kolmogorov Smirnov X2 as 1.176 with significance variable X2 (Learning Facility) was 0.126 , and the value of Kolmogorov Smirnov Y as 1.016 with significance of variable $\mathrm{Y}$ (Learning Motivation) was 0.253. The significance value $>0.05$ which meant that the data of variable X1 (Professional Competence), X2 (Learning Facility) and Y (Learning Motivation) was distributed normal.

In the auto-correlation was meant to find out whether or not there was correlation between residual in one observation with other observation. While to find out whether or not there was auto-correlation used Durbin Watson (DW) test (Santoso, 2000: 47) in Hanggara (2012: 7). It was seen from the calculation result using SPSS for Windows was obtained the value of DW of 1.897. The result of $\mathrm{DW}=1.897$ if accustomed with the table of DW value classification, the value was on $1.55-2.46$ which showed that there was now autocorrelation.

Multicollinearity test was to find out whether or not there was high correlation among the unbound variables in a model of doubled linear regression. To find whether or not there was multicollinearity can be seen by comparing VIF (Variance Inflation Factor) value. If the value of VIF calculation result was higher than $10(>10)$ then the variable had multicollinearity with other unbound variables. Conversely, if the value of VIF $<10$ then it could be said that there was no multicollinearity (Santoso, 2000: 39) in Hanggara (2012: 6).

Based on the calculation result used SPSS (Statistical Package for Social Science) 20, it was obtained the tolerance value of variable Teacher Professional Competence (X1) and Learning Facility (X2) as $0.658>0.10$. While the VIF value of variable Teacher Professional Competence and Learning Facility was $1.521<10.00$. So it could be concluded that there was no multicollinearity.

Table 6. Hypothesis test

\begin{tabular}{|c|c|c|c|c|}
\hline \multicolumn{5}{|c|}{ Model Summary } \\
\hline Model & $\mathrm{R}$ & $\begin{array}{c}\mathrm{R} \\
\text { Square }\end{array}$ & Adjusted R Square & Std. Error of the Estimate \\
\hline 1 & $.723^{\mathrm{a}}$ & .522 & .517 & 4.762 \\
\hline
\end{tabular}




\section{Iin Sunarti \& Teni Rumyani}

The effect of teacher professional competence and learning facility on students' learning motivation

From the calculation result was obtained $\mathrm{R}$ square value as 522, it meant that Teacher Professional Competence and Learning Facility affects as much as $52.2 \%$ on
Learning Motivation. While the residual as $47.8 \%$ was affected by other unobserved factors.

Table 7. The effect of teacher professional competence and learning facility on students learning motivation

\begin{tabular}{lrrrrr}
\hline \multicolumn{7}{c}{$\begin{array}{c}\text { MNOVA } \\
\text { Model }\end{array} \quad$ Sum of Squares } & Df & Mean Square & \multicolumn{1}{c}{ F } & \multicolumn{1}{c}{ Sig. } \\
$1 \quad$ Regression & 4240.509 & 2 & 2120.254 & 93.50 & $.000^{\mathrm{b}}$ \\
& & & & 2 & \\
$\quad$ Residual & 3877.606 & 171 & 22.676 & & \\
$\quad$ Total & 8118.115 & 173 & & & \\
\hline
\end{tabular}

Based on the table above was obtained $\mathrm{F}$ as 93.502 (sig. Value is $0.000<0.05$ ), so that Ho was rejected and $\mathrm{Ha}$ was accepted meaning that double regression coefficient was significant. So, Teacher Professional Competence (X1) and Learning Facility (X2) affect simultaneously and significantly on Students Learning Motivation (Y).

Table 8. Double regression analysis of variable $Y$ on $X 1$ and $X 2$

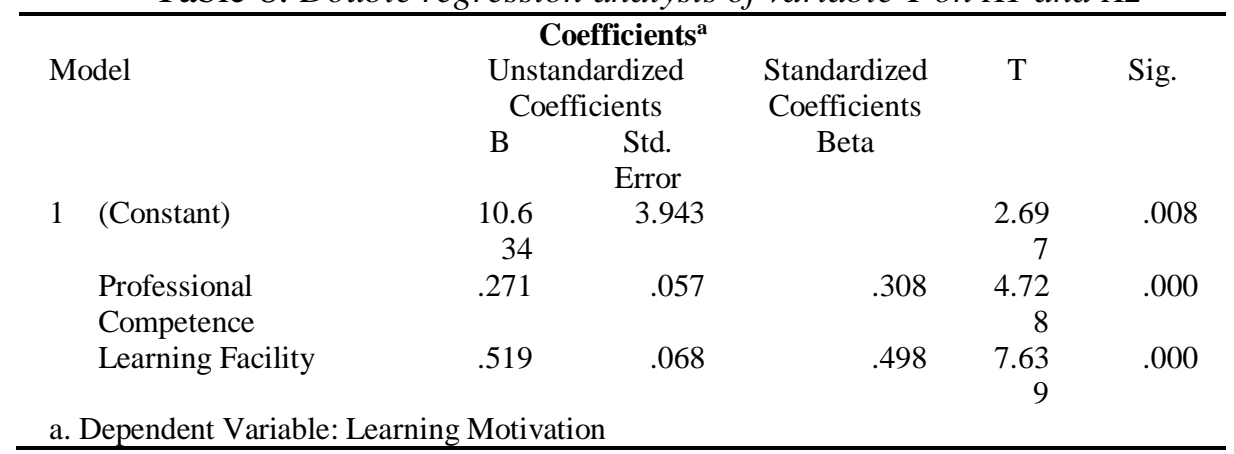

From the table 8 showed the regression equation: $\mathrm{Y}=10.634+0.271+0.519$, it showed that each accretion between $X_{1}$ and $\mathrm{X}_{2}$ as 1 will increase $\mathrm{Y}$ as $0.271+0.519$ meaning that each increased of professional competence and learning facility would increase learning motivation as well.

To test the significance (measured from the probability), from the table seen the significance of $\mathrm{X}_{1}$ and $\mathrm{X}_{2}$ as $0.000<0.05$, so $\mathrm{Ha}$ was accepted or the regression coefficient was significant.

The Teacher Professional Competence had relationship with Learning Motivation as 0.308. To test the significance (measured from the probability) from the table seen $\mathrm{t}_{\text {count }}$ as 4.728 with significance as $0.000<$ 0.05 , so Ha was accepted or the regression coefficient was significant, it meant that
Teacher Professional Competence had effect on Learning Motivation.

Beside that, Learning Facility had relationship with Learning Motivation as 0.498. To test the significance (measured from the probability) from the table seen $\mathrm{t}_{\text {count }}$ as 7.639 with significance as $0.000<$ 0.05 , so Ha was accepted or the regression coefficient was significant, it meant that Learning Facility had effect on Learning Motivation.

\section{CONCLUSION}

From the result of the research that has been conducted, the researcher drawn some conclusions, as follows: 1) Desciption of teacher professional competence, learning facility, and learning motivation has been good but not optimal yet. 2) Based on the result of simultaneous test, it shows that there was effect of teacher professional 
Indonesian Journal of Learning and Instruction Volume 1, Issue 2, October 2018

competence and learning facility on learning motivation significantly so Ha was accepted, it means that teacher professional competence and learning facility affect simultaneously and significantly on learning motivation. 3) Based on the result of partial test, it shows that there was effect of teacher professional competence on learning motivation significantly so Ha was accepted, it means that teacher professional competence affect significantly on learning motivation. 4) Based on the result of partial test, it shows that there was effect of learning facility on learning motivation significantly so Ha was accepted, it means that learning facility affect significantly on learning motivation.

\section{REFERENCES}

Arikunto, \& Suharsimi. (2006). Prosedur penelitian suatu pendekatan teknik. Jakarta: PT Rineka Cipta

Dimyati, \& Mudjiono. (2013). Belajar dan pembelajaran. Jakarta: Rineka Cipta.

Djamarah, S. B. ( 2008 ). Psikologi belajar. Jakarta: Rineka Cipta

Gie, The Liang. (2010). Cara belajar yang efisien. Yogyakarta: Lembaga Bina Prestasi.

Indriantoro, N., \& Soepomo, B. (2006). Metode penelitian bisnis untuk akuntansi dan manajemen. Yogyakarta. BPFE-Yogyakarta.

Irshad, S. M. (2013). Pengaruh kompetensi profesional guru dan fasilitas belajar terhadap hasil belajar siswa (class $x$ jurusan administrasi perkantoran SMK Negeri 2 Temanggung kompetensi dasar menggunakan peralatan kantor). Diss. Universitas Negeri Semarang.
p-ISSN 2614-8250, e-ISSN 2614-5677

https://journal.uniku.ac.id/index.php/IJLI

Krismanto, H. (2012). Pengaruh kompetensi profesional guru dan fasilitas belajar terhadap motivasi belajar siswa (studi pada siswa class $x i$ program studi administrasi perkantoran SMK Negeri 1 Batang dalam kompetensi menerapkan sistem kearsipan, (Doctoral Dissertation). Semarang: Universitas Negeri Semarang.

Mulyasa, E. (2012). Implementasi kurikulum tingkat satuan pendidikan, kemandirian guru dan kepala sekolah. Jakarta: Bumi Aksara.

Purwanto, N. (2010). Psikologi pendidikan. Bandung: PT Remaja Rosdakarya.

Sopiatin, P. (2010). Manajemen belajar berbasis kepuasan siswa. Bogor: Ghalia Indonesia.

Sanjaya, W. (2010). Kurikulum dan pembelajaran. Jakarta: Kencana.

Sardiman. (2016). Interaksi \& motivasi belajar mengajar. Jakarta: Rajawali Pers.

Slameto. (2010). Belajar dan faktor-faktor yang mempengaruhinya. Jakarta: Rineka Cipta.

Somantri, A., \& Sambas, A. M. (2011). Aplikasi statistika dalam penelitian. Bandung: Pustaka Setia.

Sudarwan, D. (2010). Media komunikasi pendidikan. Jakarta: Bumi Aksara.

Sudrajat, A. (2011). Kurikulum dan pembelajaran paradigma baru. Yogyakarta: Paramitra.

Sugiyono. (2015). Metode penelitian pendidikan. Bandung: Alfabeta.

Suharsaputra, U. (2012). Metodologi penelitian. Bandung: PT Refika Aditama.

Surya, M. (2006). Proses belajar mengajar. Bandung: PT Remaja Rosda Karya.

Syamsudin, A. (2007). Psikologi pendidikan. Bandung: PT Remaja Rosdakarya.

Uzer, M. U. (2009). Menjadi guru profesional. Bandung: PT Remaja Rosdakarya. 
Iin Sunarti \& Teni Rumyani

The effect of teacher professional competence and learning facility on students' learning motivation 